Lanas, Maija, Petersen, Eva Bendix, Brunila, Kristiina (2020) The discursive production of misbehaviour in professional literature. Critical Studies in Education.

DOI:10.1080/17508487.2020.1771604

\title{
The discursive production of misbehaviour in professional literature
}

Bad student behaviour is argued to be one of the major challenges for schools today. In response to the challenge, there is a strong body of literature aiming at fixing student behaviour. In this paper, we look into professional knowledge discourses regarding "bad student behaviour," focusing on one national context, Finland, to explore how disturbing behaviour is discursively established in the professional literature for teachers seeking help with challenging student incidents. We analyse expert sources that are readily available for Finnish teachers $(n=19)$, looking at what fields of science are represented, whose voice is represented, how the problem is defined, and where it is located. We conclude that the professional discourse about disturbing behaviour in Finland places the problem on the individual child or family while also silencing the individuals in question and portraying them as deficient. Furthermore, the sources produce a decontextualised notion of behaviour and describe it as either acceptable or unacceptable, completely overlooking any societal, historical or cultural aspects of behaviour or other mitigating circumstances. The findings resonate with research findings from other international contexts.

Keywords: student behaviour, discourse, Finland, professional literature, challenging behaviour

\section{Introduction}

The bad behaviour of students has taken centre stage in education. It is repeatedly said to be among the biggest challenges currently facing the educational system as a whole (Carter, et al., 2008; McKenna \& Flower, 2014; Närhi et al., 2015; Shaughnessy, 2012), and numerous studies and programmes are being carried out internationally to "solve the problem". There is a massive body of interventions, models, methods, management strategies, implementation programmes, tools, steps, tips, guidelines and school-level 
Lanas, Maija, Petersen, Eva Bendix, Brunila, Kristiina (2020) The discursive production of misbehaviour in professional literature. Critical Studies in Education.

DOI:10.1080/17508487.2020.1771604

policies on offer internationally. ${ }^{1}$ At the same time, it has been argued by a smaller body of research that the notion of bad behaviour (or any of its synonyms) is far from uncontested, and it is therefore also not self-evident what problem we are trying to solve (see, for example, Lanas \& Brunila, 2019; Millei et al., 2010; OFSTED, 2005).

This lack of definitional agreement in relation to the phenomenon appears in research as well as in educational practice. A literature review shows that several terms (e.g. disturbing, bad, challenging, problem, problematic, mis-, disruptive) are used in a rather common-sense and overlapping manner to refer to a wide variety of issues. To name a few, these issues may be anything from "talking out of turn" (Crawshaw, 2015; Infantino \& Little, 2005) or "non-attention" (Shen et al., 2009) to stealing, vandalism, violence (Dishion et al., 2010; Vieno et al., 2011), or silence, talkativeness, family background, representations considered masculine or feminine, expressions of subcultural identities, (lack of appropriate) emotional representations, or even handwriting (Koskela \& Lanas, 2016; Laws \& Davies, 2000; MacLure et al., 2012; Youdell, 2003). Similarly, the notion of bad behaviour is indeterminate in school practices as well; behavioural expectations have consistently been found to differ between schools, between classrooms, from one situation to another within classrooms, between the classroom and the playground, and between different students (Ball, 1981; Becker, 1952; Cicourel \& Kitsuse, 1963; HempelJorgensen, 2009; Koskela \& Lanas, 2016; Koskela \& Vehkalahti, 2016; Laws \& Davies, 2000; MacLure et al., 2012).

In this paper, we are interested in the contested conceptual terrain of bad behaviour (and its synonyms). Instead of trying to solve the lack clarity and consensus by defining the phenomenon once and for all, we want to study the discursive terrain: We take a discourse analytic view and explore what or who becomes described as disturbing/disturbing$/$ problematic/bad/mis-, and what some of the implications of that discursive positioning are. Discourses are understood here as bodies of ideas and practices that emerge within, produce power relations in, and take part in producing social reality, setting boundaries around what can be said, thought, felt, and done (Foucault, 1980). Discourses become produced in multiple ways across spheres of social or professional life, for example, in everyday practices, spoken language, media, institutions, and literature (Potter \& Wetherell, 1987). They constitute the conditions of possibility for talking about phenomena such as student "behaviour". Thus, conceptualising "disturbing behaviour" (and its synonyms) as discursive entails understanding that it is never merely a neutral description of something; it produces a particular reality with certain effects (Millei \& Petersen, 2015).

In the study at hand, we will look into the professional literature regarding disturbing behaviour. We want to enable practising teachers, including ourselves, to ask questions such as what sense does this literature, which is written to address the likes of me, help me make of student being and behaviour? What ideas does it ask me to take for granted,

\footnotetext{
${ }^{1}$ For example, see Nahgahgwon et al., 2010; Sørlie \& Ogden, 2007; Reglin et al., 2012; McKenna \& Flower, 2014; Scarpaci, 2007, Emmer \& Stough, 2001; Hester et al., 2009; Lewis et al., 2005; Sun, 2015, Wheatley et al., 2009; Fairbanks et al., 2007; Haydon \& Musti-Rao, 2011; Jeffrey et al., 2009; Ratcliff et al., 2010, Anguiano, 2001; Barbetta et al., 2005; Brainard, 2001, Gordon, 2001; Bennett, 2006; Lake, 2004; Wadesango, 2013.
} 
and what terminology does it offer for me to speak the phenomenon into existence? What is this resource asking me to feel, be or do? We will begin by explicating the problem we are trying to address, suggesting with existing research that the discourse of bad behaviour disconnects complex challenges from their contexts and places them on individual students in a quite simplified manner, ultimately portraying these individuals as deficient in various ways After that, we will analyse the literature on disturbing behaviour in one context, Finland. We will look at how the problem is defined and framed in the sources accessible to Finnish teachers and then showcase how individualisation operates in such literature, while the individuals themselves (children and youth) are silenced. The detailed analysis focuses on one context (Finland), but it is nested in an extensive reading of international research on disturbing behaviour.

\section{Discourse of bad behaviour in education}

In education, discourses of challenging behaviour are powerful in directing the sensemaking of situations with students (Lanas \& Brunila, 2019). There is a substantial body of educational research committed to identifying the individual students responsible for misbehaviours, for example, through various diagnostic tools aimed at solving the problem by fixing these individuals (e.g. Axup \& Gersch, 2008; Esin et al., 2015; Hart \& DiPerna, 2017). While such research undoubtedly produces a sense that something can be done, many authors bring up the ethical issues related to attributing the problem to individual students. As Hoffman (2009, p. 547) summarises,
When the focus is on what is "wrong" with the individual child and what can be done to change the child, attention is directed away from the equally if not more critical aspects of what can be done to change the social contexts and cultural systems in which the child is a participant - those that highlight deficiencies and make them significant in the first place.

Allen and Harwood (2016) argue that this form of individualisation produces a professional discourse in which the cultural, historical, political and social aspects of behaviour and its conceptualisations may be ignored; culturally embedded differences may be misinterpreted as "individual challenges"; emotions may be abstracted from their social and political contexts and simply evaluated in terms of "appropriateness", and particular students may become pathologised. Similarly, Gillies (2011, p. 201) states,

Pupils who dissent from sanctioned models of expression are marked out as personally lacking and are removed from mainstream classrooms to receive therapeutically styled interventions. As has been demonstrated, such deficit models fail to capture the considerably more complex and socially connected reality behind acting out in the classroom.

While the notion of "appropriate behaviour" may appear to be a neutral and commonsense descriptor, it is saturated with power relations where those embodying dominant discourses have the power to define and discipline (Maclure et al., 2012). School tends to represent the dominant discourses in a society (often some version of White middle-class heteronormativity), and students presenting allegiances to more marginal discourses may consequently be perceived as challenging dominant understandings. Almost any action 
Lanas, Maija, Petersen, Eva Bendix, Brunila, Kristiina (2020) The discursive production of misbehaviour in professional literature. Critical Studies in Education.

DOI:10.1080/17508487.2020.1771604

or conduct can be inscribed as disturbing if it suggests the wrong allegiances, as Lanas's and Youdell's studies show.

In her research, Youdell (2003) argued that in Britain, "at the level of the institution, discursive practices of Black youth/street culture [such as their way of walking] are tacitly mediated through discourses that constitute these practices as inherently challenging to the school's (or individual teacher's) authority and, by extension, the broader White hegemony" (p. 15). Lanas made a similar observation in her research (2011) conducted in a reindeer herding village school in Finnish Lapland. In the village school, mashing potatoes with a fork prior to eating them was forbidden as an uncivilised northern custom. Instead, students were to cut potatoes with a fork and a knife, and any students mashing their potatoes were interpreted as misbehaving: They were seen to question their need to be civilised and thus to challenge the authority of the teacher and the southern hegemony in determining values such as "good behaviour" and a "good life" for villagers. Interestingly, mashing potatoes is not forbidden or even viewed negatively in southern cities. In this way, although disturbing behaviour in school is commonly associated with a student's lack of social skills and lack of engagement, it may also just be considered at times to be a wilful allegiance with the "wrong" communities and their "wrong" practices.

Ignoring such sociopolitical matters, individualisation directs the attention of researchers, policy-makers and teachers - and even the students and their families - away from the cultural and historical contexts of student behaviour and replaces these with a decontextualised fixation on norms and standards in a manner that leads to pathologisation of those who do not conform to these. In contrast, the actions of the youth (walking, eating potatoes) in the above examples could be engaged with as an opportunity to discuss differences in cultural practices and norms, for a co-exploration of power relations, and as an invitation for students to participate in defining acceptable practices at school. The impetus here is not to fix the deficient individual in relation to some ostensible universal norm. Accordingly, if the students' actions are engaged with outside the impetus to pathologise and fix, then their actions can be read radically differently. Lanas, for example, found that the perceived student misbehaviour in the northern reindeer village school was motivated by student efforts to stand up for their culture and explore and find balances between the diverse social codes of school and local culture, as well as frustration brought on by these efforts. Gillies (2011, p. 201) made similar readings in her study, where students emphasised "a strong sense of social belonging, displaying allegiances to (amongst other things) their ethnic groups, neighbourhood, schools." Gillies argued that the perceived bad behaviour may be not so much a "lack of engagement" as engaging with several mutually conflicting discourses and ways of life. Thus, the "disturbance" may not be deliberate and might occur through multiple seemingly mundane incidents that not only disturb the silent hegemony of the dominant discourses but also might make such a hegemony momentarily visible. This can be experienced as quite disturbing to those who identify with these dominant discourses, and thereby, the behaviour that led to the unmasking becomes branded as a disturbing behaviour.

\section{Focusing on the professional literature on bad behaviour in Finland}


To further explore how students' behaviours (actions, ways of being) are made sense of in contemporary educational contexts, in this study, we focussed on the professional literature available for Finnish reading teachers. Through an investigation of this literature in one national context, the aim is to illuminate some of the discursive repertoires pervading professionally validated knowledge about children and youth at school. We are, first and foremost, interested in how these resources help teachers make sense of situations and, as a consequence, help them determine the best course of action in their practice; however, we are also curious about the extent to which the critical research literature in the field (some of which we have referenced above) has made a significant impact on these resources.

The Finnish context makes for an interesting case study in various ways. Following successive high-ranking placements on PISA lists (OECD, 2019), it has in various ways been positioned as the best educational system in the world, and there has been significant interest in determining the causes for this success. Amongst various factors, the teachers' level of education, the requirements for admission to a teaching degree programme, and their level of professional autonomy have been put forward as key factors (e.g. Hammerness et al., 2017). Teachers are nationally respected and viewed as professional experts, free to develop their own practices and responses to challenges with the help of up-to-date research. All the usual means of controlling teachers that are seen internationally are not used here: there are no inspectorates, standardised tests, obligatory diaries or materials. There are also no official programmes, guidelines or standard practices for managing student behaviour. Instead, teachers are considered autonomous professionals capable of accessing relevant resources, on which they are expected to base their pedagogical decision-making. Therefore, it is pertinent to investigate the resources that are available for them to enhance their practice, including the professional literature. In this particular study, we will not be able to say how Finnish teachers make sense of and work with this literature; we will merely offer a reading of the discourses that are being made available to them. As mentioned earlier, an important aim for us is to enable critical conversations about current expert knowledge concerning student (mis)behaviour.

\section{Constructing an archive}

For this study, we considered what a Finnish reading teacher encountering challenges in his or her classroom might do to figure out how to best proceed. Of course, it is likely that he or she would talk to colleagues, particularly experienced colleagues, and other school-appointed advisers. He or she might also seek out professional development opportunities, peruse the internet, revisit materials used during their teacher education, and so on. Further, given the expectations that follow from holding a higher academic degree, we also considered that a teacher might look to research and other published academic literature. Going on from there, we decided to construct what we call an archive of Finnish professional literature about disturbing behaviours of students.

Following Thiem (2014), we here understand an archive as "not an institution with a physical existence" or anything with clear boundaries. Archives, according to Thiem, need not contain coherent wholes. Rather, an archive bears down on individuals and groups as social imagery. It shapes individual bodies, desires, aspirations, fears, hopes, 
and other affects in relation to the available social registers of representations and meanings and becomes coded with implicit normativity and desirability or undesirability. In other words, an archive, as it is seen here, is the historical fragments and received wisdom shaping the professional mindset. The archive produced in this way is not a systematic literature review, which may provide (or give the impression that it provides) an understanding of all research that has been published on the issue; neither is it an entire shelf in a particular physical library. Rather, the archive we have constructed is a corpus of a broad selection of authoritative sources legitimated by being released by publishing houses, governments and school leaders - meaning they are the type of sources a Finnish reading teacher would likely consider professionally credible.

In constructing this archive of credible professional literature, we selected the sources that we deemed our imaginary teacher would be likely to access. To do this, we conducted online searches with all Finnish terms ${ }^{2}$ for disturbing behaviour, problem behaviour or challenging behaviour. From this set, we selected material using the following criteria:

(1) Professional: written by authorities and experts and published by an official or professional body (thus excluding blogs by teachers, but including a website administered by the Ministry of Education). We excluded bachelor's or M.Ed theses as unlikely, although not unthinkable, sources for busy teachers.

(2) Easily accessible: available in Finnish (although the internet is full of material in other languages, some of which many Finnish reading teachers are likely able to read); available on the internet or in the library and freely accessible or with a regular library card, readable for professionals (e.g. non-researchers).

(3) Targeted at educators and those who work with children and youth, thus excluding books meant only for parents. One of the sources is one city's official guidelines for teachers, and it was included in the material because it was recent, official and appeared in online searches outside of the city that had published it. We ruled out sources meant primarily for medical, psychological or psychiatric experts.

(4) Reasonably recent: published within the past 15 years. Two exceptions were accepted as a part of the data, specifically, one book published in 2002 and one published in 1998, because they are still commonly checked out of the library (many copies' status in the library showed "on loan").

Based on the above criteria, we suggest that a practitioner of education (children and youth) looking for literature in Finnish on bad behaviour will easily find access to 19 different, fairly recent, professional sources. An overview is presented in Table 1 (all the sources in the archive are listed in full in the references), organised according to publisher, type of source, field, and author/year. Each source has a number, which we will refer to below.

\section{Table 1}

\footnotetext{
${ }^{2}$ häiriökäytös, häiritsevä käytös, ongelmakäytös, haastava käytös, and lapsi, nuori
} 
Lanas, Maija, Petersen, Eva Bendix, Brunila, Kristiina (2020) The discursive production of misbehaviour in professional literature. Critical Studies in Education.

DOI:10.1080/17508487.2020.1771604

In our initial examination, we pursued the following questions: Which fields of science were represented? Who were the expert voices? What is stated as the problem? What are the reasons for the problem? Where is the problem located? What should be done to solve it? What is the child/youth's position and the adult's position?

The analytical approach we took thereafter was inductive discourse analysis in that we identified key words and phrases in the material and then clustered them together in relation to the wider discourses they cited and produced (Whetherell et al., 2001). The purpose for this kind of analysis was to make visible the normalised and implicit assumptions upheld in the professional literature. The analysis does not presume to make claims about individual sources in relation to other publications by the same authors. Instead, the purpose is to illuminate the production of discourses of disturbing behaviour.

\section{Discourses of bad behaviour in the literature}

To begin with, the titles of the sources are informative about which discourses are operative in constituting "disturbing behaviour". A few translated examples:

- Silence the disturber with positivity - research-based knowledge about preventing behavioural problems $\underline{3}$

- Virtue Pedagogy as a method of solving behavioural problems

- Personal safety in school: predicting and managing dangerous behaviour

- Facing children's and youth's behavioural problems

- The explosive child: a new approach to understanding and bringing up easily frustrated and inflexible children

- Challenging behaviour of a student and facing it in Jyväskylä's basic education services

- Facing the psychological problems of a youth

The archive, when imagined as book covers on a bookshelf, portrays an image of problems. The problematic nature of the child/youth in question is taken at face value. A more careful look into the contents of the sources shows that the knowledge regarding disturbing behaviour in the professional literature is characterised by two elements: On the one hand, problems are individualised and societal challenges are overlooked; on the other hand, the individuals themselves (children and youth) are silenced in regard to their own issues. Below, we will further substantiate these observations.

\section{Problems are individualised and societal challenges are silenced}

What is striking is that the sources present the problem, its reasons, location and solutions in almost unanimous ways. The perceived problem is placed on the individual child/youth or their immediate surroundings. The reasons for the problem behaviour become located either within the individual young person or in their family background. For example, Source 6 lists as reasons inheritance, parenting, peer relations, ADHD, early puberty, lack of social skills and parental substance abuse. Similarly, Source 8 states

\footnotetext{
${ }^{3}$ All of the direct translations used here are rather clumsy, but eloquent translations would require interpretation.
} 
[The problem may be rooted in] the child him/herself (attention deficit or hyperactivity) or to the child's environment and its changes (difficult experiences in early childhood and placement in a foster family) or both together.

The effects of media and peers are mentioned as modelling behaviour of older students, or learned behaviour from media, but such effects are discussed once and briefly as an individual young person's tendency to choose bad role models. In a few instances, the problem was also located in school practices, but here only focussing on how such practices should more successfully fix the (behaviour of) individual problematic students.

Two perspectives were notably lacking. First, there was little recognition of how school practices may themselves produce the problem, although research has repeatedly shown that common school practices (e.g. favouring some cultural practices in school) produce unequal experiences of schooling for different students and that preferences or perceptions of behaviour are social-historical-cultural. These insights were, however, not present in the sources. For example, Source 16 (explicitly meant as instructions for teachers) lists the reasons for challenging behaviour:

Physical (pain, illnesses), psychological, social (lack of skills, family problems, unsuitable environment for the individual).

All of these reasons are described so that they are placed within the student. Even "physical reasons" are here construed as having nothing to do with, for example, the school's architecture, floor plan, furniture or geography, but only with physiological conditions of individuals perceived as problematic.

Second, there was no discussion of the cultural-historical-economic-societal roots of the perception of behaviour. There was no push to reflect upon why an educator might perceive specific behaviours as problematic. The sources repeatedly emphasised that the children or young people should not be seen as responsible or be blamed for their behaviour, that attention should be paid to how the background of the child impacts their behaviour. Behaviour was thereby seen as the child's possession, rooted in the child and their background, not in the context in which it is inscribed with meaning. The said "background" almost univocally came to be defined as "parents", and the impact of issues such as racialising and gendering practices, homophobia, ableism, economic differences and other forms of discrimination were not recognised as "background". Background simply means deficient parents and parenting.

The lack of these perspectives in Finnish professional literature links to broader professional discourses that do not tend to recognise inequality in Finnish education (Koski \& Filander, 2013). As is well known within the current global educational discourse, the Finnish school system is highly comprehensive, and there is little economic stratification when compared internationally. The hegemonic and dominant discourses regarding Finnish educational equality produce the belief that inequality is a non-issue in Finland (ibid.). Social and cultural differences have, according to popular conception, been abolished (ibid.). Therefore, any student agency deriving from or attempting to point out such inequalities may lack discursive frameworks that validate the experience of inequality. 
The lack of societal or cultural perspectives in the sources makes sense when looking at the expert voice: seven expert voices were those of psychiatry/psychology, seven were from special education, four were from experienced teachers and one was from an educational administrator. In addition, there was one voice from social and health care and one non-referred. Therefore, in professional delineations of disturbing behaviour, the expert voices tend to come from the fields of psychology and psychiatry as well as special education, which draws heavily on these disciplines (Watson et al., 2018). None of the sources in our archive were written by authors with sociological, historical or philosophical expertise, and youth studies or childhood studies were not represented.

The language was medicalised but inaccurate. For example, "disorderly behaviour" (häiriökäytös) and "behavioural disorder" (käytöshäiriö) were often used interchangeably in the sources. Whereas the latter, in the field of psychology and psychiatry is likely grounded in a long tradition of research, the former is, as depicted above, remarkably undefined and unspecific. By mixing these two terms, the scientific validity of the psychological term is extended to the un-academic idea of disturbing behaviour, and the sources speak of it as if it were defined (which it was not) with similar precision.

\section{Children and youth are silenced}

The children and youth perceived as disturbing were the "silent centre" in the professional literature about them. By this, we mean that although the literature focussed on disturbing youth and children, such youth were presented only as targets of actions, not as meaningmakers and agents themselves. For over three decades, childhood studies and youth studies (e.g. Kallio \& Häkli, 2015) have discussed the political agency of children and youth and developed methods to listen to them "in their own right" (Hardmann, 1973). However, we find no reference to such discussions and research in the sources in our archive. Instead, children and youth are approached as something to be fixed, managed or handled — not someone to be heard or someone who might have something worthwhile to say.

For example, although the titles and the content regularly speak of "facing", such facing does not extend to the individual child or youth, but only to facing the disorder or the problem placed in them:

Facing children's and youth's behavioural problems (Source 13, title)

Facing the psychological problems of a youth (Source 17, title)

It has been experienced as necessary to define principles and courses of action with which to face student's challenging behaviour in the school life. (Source 16, p. 1)

The notion of facing, then, easily becomes associated with combat metaphors, where we "face the enemy". As a discourse, it invites a teacher to feel, think and act on its terms. The literature also commonly defines the child or youth based on the problem, as a "disturber", "challenging youth", or "children with a behavioural disorder". The child or youth who has been defined based on the problem is not faced or listened to but is instead an unspeaking deficient target on which professional knowledge is applied:

Silence the disturber (Source 15, title) 
Lanas, Maija, Petersen, Eva Bendix, Brunila, Kristiina (2020) The discursive production of misbehaviour in professional literature. Critical Studies in Education.

DOI:10.1080/17508487.2020.1771604

The child acts in social situations with insufficient skills. (Source 10, p. 51)

Youth with behavioural disorders have common features such as bad empathy skills, interpreting the motivations of others' actions wrong, inability to feel guilt or regret, bad self-esteem (disguised as tough-guy role), bad skills in handling disappointment and controlling impulses, and difficulties in social relationships. (Source 7, p. 28)

As we can see, in describing the problem that teachers 'face', children are being described and defined in particular ways. If empathy is the ability to understand and share the feelings of the other, a question arises as to precisely who demonstrates a lack of such skills.

\section{Subjectivating effects of the discourse of bad behavior}

Discourses are meaning-making operations, and they come to matter when persons or subjects take them up as their own. This take-up is not necessarily conscious. Subjects become vehicles of certain knowledge regimes, and these regimes stipulate the appropriate ways of thinking, feeling and doing. This is why and how the discourses offered in the professional literature are significant. They ask teachers to make sense of what occurs in their work life in a particular way. Mastering this discourse may lead to a sense of competence, of knowing the problem and knowing how to act, and this competence is shared when teachers help each other figure out what to think and do about something.

When teachers are invited to think about disturbing behaviour as belonging to an individual child, it has many implications. Key among those are both the idea of the decontextualised child - a child without social, economic and cultural situation - and the deficient child, who may or may not have a psychological and psychiatric issue. Interestingly, the psy-sciences remain as a contextual explanatory framework, and these tend to sustain the gaze upon the individual and inside the individual (Petersen \& Millei, 2015). The teacher subject therefore becomes a behaviour management professional with a psy-gaze and a keen interest in all the diagnostic tools and terminology that this entails. In turn, the child subject becomes a subject of this psy-gaze and can only be known and interacted with on those terms. The discourse sets it up so that this child cannot be recognised as heroic, loyal, tenacious, self-sustaining and disciplined. And the relationship between the teacher and the child cannot be read as one of mutual respect, dialogue and negotiation, but rather as one in which the teacher faces the adversarial breaker of rules and norms. As others have shown (MacLure et al., 2012), once a child is recognised as disturbing, that child and his or her actions become interpreted only within that framework. The subjectification of both the teacher and the student subject continues, and in that way, both get caught in a particular discourse.

\section{Conclusion}


As our study has shown, the professional sources readily available to Finnish reading teachers perpetuate particular discourses of disturbing behaviour. Importantly, they are similar and therefore also sustain, rather than question, each other's perspectives and claims. Teachers who pick up just a handful of the 19 resources we identified might come to believe that this way of making sense is universal or, indeed, uncontested. They might come to believe that this is the natural and only way of thinking about, talking about, and feeling about the difficulties they surely encounter.

Especially in contexts such as Finland, where teachers are positioned as professional experts and who must create solutions based on continual engagement with resources, it is crucial to critically analyse what kinds of knowledge are accessible to them in these resources. In the context of this research, deficit discourses become validated by publishing houses, disability and welfare unions, medical societies, teachers' online services, city officials, and institutes.

As already mentioned, apart from being interested in these resources and their statements, truth claims, and tips and tricks, we were interested to see the extent to which the critical perspectives of the decontextualised, deficit psy-based discourses, and the implications of these discourses, which have been available for several decades, had made an entry into the readily available resources for practising teachers. Were there any openings for alternative interpretations of "problem" behaviour? Were the sources critically reflective about their own positionings and truth claims? Was there any reference to research critical of individualising discourses? In other words, did they offer themselves up as possible meaning-makers and make it possible for teachers to explore alternative viewpoints? As we have shown, these 19 sources in our archive did not. This suggests to us that there is a serious need for alternative perspectives in the easily accessible resources for practising teachers. Teachers are more than capable of making up their own minds, but if they do not have access to discourses that contest the ways of knowing, feeling and acting that are stipulated in the mainstream literature, then this task becomes all the more difficult.

We conclude, therefore, that in Finnish schools, there is a real risk that the decontextualised deficit discourse of disturbing behaviour maintains itself. The cultural, social, economic and historical aspects of schools and student lives may exist in professional literature, but they do not come up when looking for guidance about challenging situations with students. There seems to be a disconnection between bodies of literature. To access these other archives, a teacher would possibly have to already characterise the perceived challenge as a social justice issue and conduct searches with different keywords, for example in the field of intercultural studies, childhood studies, youth studies or even human geography, and construct the local practical implications on one's own. Most critical literature, or the literature committed to destabilising hegemonic discourses, have not been turned into practical manuals for the busy working teacher. In this way, the discourse keeps itself going: a teacher looking for information about tackling disturbing behaviour finds just that, and there is little space for questioning the implicit assumptions. This has significant implications for the lives of teachers and students in schools.

\section{References}


Lanas, Maija, Petersen, Eva Bendix, Brunila, Kristiina (2020) The discursive production of misbehaviour in professional literature. Critical Studies in Education.

DOI:10.1080/17508487.2020.1771604

Anguiano, P. (2001). A first-year teacher's plan to reduce misbehaviour in the classroom. Teaching Exceptional Children, 33(3), 52. Axup, T., \& Gersch, I. (2008). The impact of challenging student behaviour upon teachers' lives in a secondary school: Teachers' perceptions. British Journal of Special Education, 35(3), 144151. doi:10.1111/j.1467-8578.2008.00388.x

Baker, J. A., Clark, T. P., Crowl, A., \& Carlson, J. S. (2009). The influence of authoritative teaching on children's school adjustment: Are children with behavioural problems differentially affected? School Psychology International, 30(4), 374-382. doi:10.1177/0143034309106945

Ball, S. J. (1981). Beachside comprehensive: a case-study of secondary schooling (Repr. ed.). Cambridge: Cambridge U.P.

Barbetta, P. M., Norona, K. L., \& Bicard, D. F. (2005). Classroom behaviour management: A dozen common mistakes and what to do instead. Preventing School Failure: Alternative Education for Children and Youth, 49(3), 11-19. doi:10.3200/PSFL.49.3.11-19

Becker, H. (1952). Social class variations in the teacher-pupil relationship. The Journal of Educational Sociology: A Magazine of Theory and Practice, 25, 451-466.

Bennett, P. L. (2006). Helpful and unhelpful practices in meeting the needs of pupils with emotional and behavioural difficulties: A pilot survey of staff views in one local authority. British Journal of Special Education, 33(4), 188-195. doi:10.1111/j.1467-8578.2006.00438.x

Brainard, E. (2001). Classroom management: Seventy-three suggestions for secondary school teachers. Clearing House, 74(4), 207.

Carter, M., Stephenson, J., \& Clayton, M. (2008). Students with severe challenging behaviour in regular classrooms: Support and impacts. Australian Journal of Guidance and Counselling, 18(2), 141-159. doi:10.1375/ajgc.18.2.141

Cefai, C., \& Cooper, P. (2010). Students without voices: The unheard accounts of secondary school students with social, emotional and behaviour difficulties. European Journal of Special Needs Education, 25(2), 183-198. doi:10.1080/08856251003658702

Cicourel, A. V., \& Kitsuse, J. I. (1963). The educational decision-makers. Indianapolis: Bobbs-Merrill.

Crawshaw, M. (2015). Secondary school teachers perceptions of student misbehaviour: A review of international research, 1983 to 2013. Australian Journal of Education, 59(3), 293-311. doi:10.1177/0004944115607539

Dishion, T. J., Véronneau, M., \& Myers, M. W. (2010). Cascading peer dynamics underlying the progression from problem behaviour to violence in early to late adolescence. Development \& Psychopathology, 22(3), 603-619. doi:10.1017/S0954579410000313

Edu.fi (2010) Lasten ja nuorten sosio-emotionaaliset vaikeudet - mikä avuksi? [Socioemotional problems of children and youth - what could help?] (Risto Hotulainen, Matti Kuorelahti, Kristiina Lappalainen \& Jarto Tanskanen 2010) ${ }^{4}$

Emmer, E. T., \& Stough, L. M. (2001). Classroom management: A critical part of educational psychology, with implications for teacher education. Educational Psychologist, 36(2), 103-112. doi:10.1207/S15326985EP3602_5

\footnotetext{
${ }^{4}$ This source was available on the Edu-fi-website of the ministry of Education until 2017. It can no longer be located online, although the authors do list it in their publications
} 
Lanas, Maija, Petersen, Eva Bendix, Brunila, Kristiina (2020) The discursive production of misbehaviour in professional literature. Critical Studies in Education.

DOI:10.1080/17508487.2020.1771604

Ervasti, J., Kivimäki, M., Puusniekka, R., Luopa, P., Pentti, J., Suominen, S., . . . Virtanen, M. (2012). Association of pupil vandalism, bullying and truancy with teachers' absence due to illness: A multilevel analysis. Journal of School Psychology, 50(3), 347-361. doi:10.1016/j.jsp.2011.11.006

Esin, I. S., Dursun, O. B., Acemoglu, H., \& Baykara, B. (2015). Psychopathology and related psychosocial factors in children with office discipline referrals at school: Evidence from a developing country. Community Mental Health Journal, 51(7), 867-878. doi:10.1007/s10597-015-9861-9

Fairbanks, S., Sugai, G., Guardino, D., \& Lathrop, M. (2007). Response to intervention: Examining classroom behaviour support in second grade. Exceptional Children, 73(3), 288-310.

Flouri, E., Mavroveli, S., \& Midouhas, E. (2013). Residential mobility, neighbourhood deprivation and children's behaviour in the UK. Health and Place, 20, 25-31. doi:10.1016/j.healthplace.2012.12.002

Gillies, V. (2011). Social and emotional pedagogies: Critiquing the new orthodoxy of emotion in classroom behaviour management. British Journal of Sociology of Education, 32(2), 185-202. doi:10.1080/01425692.2011.547305

Gordon, D. G. (2001). Classroom management. Music Educators Journal, 88(2), 17.

Grant, B. (1997). Disciplining students: The construction of student subjectivities. British Journal of Sociology of Education, 18(1), 101-114. doi:10.1080/0142569970180106

Greene, R. W., \& Muurinen, M. (2009). Koulun hukkaamat lapset: Opas käytösongelmaisten lasten auttamiseksi. [Children lost by school: a manual ${ }^{5}$ for helping children with behavioural problems]. Helsinki: Finn Lectura.

Greene, R. W., \& Tervonen, E. (2006). Tulistuva lapsi: Uusi lähestymistapa helposti turhautuvien ja joustamattomien lasten ymmärtämiseen ja kasvattamiseen. [The fiery (explosive) child: a new approach to understanding and bringing up easily frustrated and inflexible children]. Helsinki: Finn Lectura.

Hammerness, K., Ahtiainen, R., \& Sahlberg, P. (2017). Empowered Educators in Finland: How High-Performing Systems Shape Teaching Quality. San Francisco, CA: Jossey-Bass.

Hammersley, M. (2017). Childhood studies: A sustainable paradigm? Childhood, 24(1), 113-127. doi:10.1177/0907568216631399

Hardmann, C. (1973). Can there be an anthropology of children? Journal of The Anthropological Society of Oxford, 4(2), 85-99.

Hart, S. C., \& DiPerna, J. C. (2017). Teacher beliefs and responses toward student misbehaviour: Influence of cognitive skill deficits. Journal of Applied School Psychology, 33(1), 1-15. doi:10.1080/15377903.2016.1229705

Haydon, T., \& Musti-Rao, S. (2011). Effective use of behaviour-specific praise: A middle school case study. Beyond Behaviour, 20(2), 31-39.

Hempel-Jorgensen, A. (2009). The construction of the 'ideal pupil' and pupils' perceptions of 'misbehaviour' and discipline: Contrasting experiences from a low-socio-economic and a high-socio-economic primary school. British Journal of Sociology of Education, 30(4), 435-448. doi:10.1080/01425690902954612 
Lanas, Maija, Petersen, Eva Bendix, Brunila, Kristiina (2020) The discursive production of misbehaviour in professional literature. Critical Studies in Education.

DOI:10.1080/17508487.2020.1771604

Hester, P. P., Hendrickson, J. M., \& Gable, R. A. (2009). Forty years later -- the value of praise, ignoring, and rules for preschoolers at risk for behaviour disorders. Education \& Treatment of Children, 32(4), 513-535.

Hoffman, D. M. (2009). Reflecting on social emotional learning: A critical perspective on trends in the united states. Review of Educational Research, 79(2), 533-556.

Infantino, J., \& Little, E. (2005). Students' perceptions of classroom behaviour problems and the effectiveness of different disciplinary methods. Educational Psychology, 25(5), 491-508. doi:10.1080/01443410500046549

Jeffrey, J. L., McCurdy, B. L., Ewing, S., \& Polis, D. (2009). Classwide PBIS for students with EBD: Initial evaluation of an integrity tool. Education \& Treatment of Children, 32(4), 537-550.

Jyväskylän kaupunki (2015). Oppilaan haastava käytös ja sen kohtaaminen Jyväskylän perusopetuspalveluissa, 17. [Challenging behaviour of a student and facing it in Jyväskylä's basic education services.] Jyväskylän Kaupunki, Perusopetuspalvelut, palvelunjohtajan ohje [Instructions by the service manager].2015.

Kallio, K.P \& Häkli, J. (2015) Children and young people's politics in everyday life. The Beginning of Politics, 1-16. London and New York: Routledge.

Kayikçi, K. (2009). The effect of classroom management skills of elementary school teachers on undesirable discipline behaviour of students. Procedia - Social and Behavioural Sciences, 1(1), 1215-1225. doi:10.1016/j.sbspro.2009.01.218

Kiiski, Tiina (no year) Työrauhaa Kaikille, tukitoimimalli yläkoulujen työrauhaongelmiin. [Bringing working peace for all, a model of action to lessen working peace problems]. Niilo Mäki -instituutti.

Koskela, A., \& Lanas, M. (2016). Fabricating expert knowledge of the behaviour of problematic students. Pedagogy, Culture \& Society, 24(3), 459-471. doi:10.1080/14681366.2016.1196232

Koskela, A., \& Vehkalahti, K. (2016). Child in a form: The definition of normality and production of expertise in teacher statement forms - the case of northern finland, 1951-1990. Paedagogica Historica, , 1-17. doi:10.1080/00309230.2016.1267780

Kuorelahti, M. Käyttäytymisen ongelmat ja niiden luokittelu. [Problems of behaviour and their classification]. teoksessa: Vehmas, S., Ladonlahti, T., Naukkarinen, A., Ahvenainen, O., Hiitola, B., Holopainen, E., Virtanen, P. (1998). Poikkeava vai erityinen?: Erityispedagogiikan monet ulottuvuudet. [Jyväskylä]: Atena.

Kyllönen, T., \& Rickman, A. (2011). Henkilöturvallisuus koulussa: Vaarallisen käytöksen ennakointi ja hallinta. [Personal safety in school: predicting and managing dangerous behaviour]. Jyväskylä: PS-kustannus.

Laajasalo, Taina (2016). Hiljennä häirikkö hyvällä - tutkittua tietoa käytösongelmien ehkäisystä. [Silence the disturber with positive: research-based knowledge of preventing behavioural problems] In: Ahtola, A. (2016). Psyykkinen hyvinvointi ja oppiminen [psychical wellbeing and learning]. Jyväskylä: PS-kustannus

Lake, V. E. (2004). Ante up: Reconsidering classroom management philosophies so every child is a winner. Early Child Development \& Care, 174(6), 565-574. doi:10.1080/0300443042000187077

Lanas, M. (2011). Smashing potatoes: Challenging student agency as utterances. Oulu: University of Oulu. 
Lanas, Maija, Petersen, Eva Bendix, Brunila, Kristiina (2020) The discursive production of misbehaviour in professional literature. Critical Studies in Education.

DOI:10.1080/17508487.2020.1771604

Lanas, M., \& Corbett, M. (2011). Disaggregating student resistances, analysing what students pursue with challenging agency. Young, the Scandinavian Journal of Youth Studies, 19(4), 415-432.

Lanas, M., \& Kelchtermans, G. (2015). "This has more to do with who I am than with my skills" - student teacher subjectification in finnish teacher education. Teaching and Teacher Education, 47, 22-29.

Lanas, M., Rautio, P., \& Syrjala, L. (2013). Beyond educating the marginals: Recognizing life in northern rural finland. Scandinavian Journal of Educational Research, 57(4), 385-399. doi:10.1080/00313831.2012.656283

Laukkanen, E., \& Aalberg, V. (2006). Nuoren psyykkisten ongelmien kohtaaminen. [Facing the psychological problems of a youth] Helsinki: Duodecim.

Law, Helena (2010) hyvekasvatuksesta väline käytösongelmien ratkaisemiseen. [Virtue pedagogy as a method to solve behavioural problems]. Kasvatus 41(3). 287-289.

Laws, C. (2011). Poststructuralism at work with marginalised children. [S.1.]: Bentham Science.

Laws, C., \& Davies, B. (2000). Poststructuralist theory in practice: Working with "behaviourally disturbed" children. International Journal of Qualitative Studies in Education, 13(3), 205-221. doi:10.1080/09518390050019631

Lewis, R., Romi, S., Qui, X., \& Katz, Y. J. (2005). Teachers' classroom discipline and student misbehaviour in australia, china and israel. Teaching \& Teacher Education, 21(6), 729-741. doi:10.1016/j.tate.2005.05.008

Lindh, R., \& Sinkkonen, H. (2009). Koulusta selviytyminen: Opettajan ja oppilaan yhteinen haaste. [Surviving school: a shared challenge for teacher and student] Helsinki: Palmenia Helsinki University Press.

MacLure, M., Jones, L., Holmes, R., \& MacRae, C. (2012). Becoming a problem: Behaviour and reputation in the early years classroom. British Educational Research Journal, 38(3), 447-471. doi:10.1080/01411926.2011.552709

Marttunen, M., Huurre, T., Strandholm, T., \& Viialainen, R. (2013). Nuorten mielenterveyshäiriöt: Opas nuorten parissa työskenteleville aikuisille. [Mental disorders of youth: a manual for adults working with children] Helsinki: Terveyden ja hyvinvoinnin laitos.

McKenna, J. W., \& Flower, A. (2014). Get them back on track: Use of the good behaviour game to improve student behaviour. Beyond Behaviour, 23(2), 20-26.

Millei, Z., T. G. Griffiths, and R. J. Parkes, eds. 2010. Re-Theorizing Discipline in Education: Problems, Politics, and Possibilities. New York: Peter Lang

Morrison, G. M., You, S., Sharkey, J. D., Felix, E. D., \& Griffiths, A. J. (2013). Mediation of school bonding and peer norms on the reciprocal effects of friend victimization and problem behaviour. School Psychology International, 34(1), 101-120. doi:10.1177/0143034312440214

Nahgahgwon, K. N., Umbreit, J., Liaupsin, C. J., \& Turton, A. M. (2010). Function-based planning for young children at risk for emotional and behavioural disorders. Education \& Treatment of Children, 33(4), 537-559.

Närhi, V., Kiiski, T., Peitso, S., \& Savolainen, H. (2015). Reducing disruptive behaviours and improving learning climates with class-wide positive behaviour support in middle schools. European Journal of Special Needs Education, 30(2), 274-285. doi:10.1080/08856257.2014.986913

OECD (2019). Country Note, Finland, PISA 2018 Results. Volumes I-III. https://www.oecd.org/pisa/publications/PISA2018_CN_FIN.pdf 
Lanas, Maija, Petersen, Eva Bendix, Brunila, Kristiina (2020) The discursive production of misbehaviour in professional literature. Critical Studies in Education.

DOI:10.1080/17508487.2020.1771604

OFSTED. (2005). A study of children and young people who present challenging behaviour. Retrieved from http://www.scie-socialcareonline.org.uk/a-study-ofchildren-and-young-people-who-present-challenging-

behaviour/r/a11G00000017tcxIAA

O'Regan, F., \& Virtanen, A. (2012). Haastava käytös: Käytännön neuvoja ja menetelmiä, miten ymmärtää ja käsitellä haastavasti käyttäytyvää lasta. [Challenging behaviour: practical instructions and methods, how to help understand, manage a child who behaves challengingly]. Helsinki: Kehitysvammaliitto, oppimateriaalikeskus Opike.

Ratcliff, N. J., Jones, C. R., Costner, R. H., Savage-Davis, E., \& Hunt, G. H. (2010). The elephant in the classroom: The impact of misbehaviour on classroom climate. Education, 131(2), 306-314.

Reglin, G., Akpo-Sanni, J., \& Losike-Sedimo, N. (2012). The effect of a professional development classroom management model on at-risk elementary students' misbehaviours. Education, 133(1), 3-18.

Ruoho, Kari; Ihatsu, Markku \& Kuorelahti, Matti (2002). Käyttäytymishäiriöiset lapset ja nuoret. [Children and youth with behavioural disorders] In: M. Jahnukainen, Lasten erityishuolto ja -opetus Suomessa [Special care and education in Finland] (11. [i.e. 12.] täydennetty p.). Helsinki: Lastensuojelun keskusliitto. 249-265

Saloviita Timo (2014) Työrauha luokkaan [Bringing working peace to the class]. PSKustannus.

Savolainen, Tuija (2010): Haastava nuori ja koulunkäynti- opas opettajalle. [Challenging youth and going to school - a manual for teachers] Tuusula: Tuusulan kunnan monistamo. Www.kalliomaa.net.

Scarpaci, R. T. (2007). IOSIE: A method for analyzing student behavioural problems. Clearing House, 80(3), 111-116.

Sekula, Allan. 1986. The Body and the Archive. October (39). 3 -64.

Sekula, Allan. 2002. Reading an Archive: Photography Between Labour and Capital. in Liz Wells (Ed.). The Photography Reader. London: Routledge. Pages 443-452

Shaughnessy, J. (2012). The challenge for english schools in responding to current debates on behaviour and violence. Pastoral Care in Education, 30(2), 87-97. doi:10.1080/02643944.2012.679954

Shen, J., Zhang, N., Zhang, C., Caldarella, P., Richardson, M. J., \& Shatzer, R. H. (2009). Chinese elementary school teachers' perceptions of students' classroom behaviour problems. Educational Psychology, 29(2), 187-201. doi:10.1080/01443410802654909

Simola, H., Rinne, R., Varjo, J., Pitkanen, H., \& Kauko, J. (2009). Quality assurance and evaluation (QAE) in finnish compulsory schooling: A national model or just unintended effects of radical decentralisation? Journal of Education Policy, 24(2), 163-178. doi:10.1080/02680930902733139

Sinkkonen, J. (2015). Pulassa lapsen kanssa [In trouble with a child]. Helsinki: Duodecim.

Soisalo, R. (2012). Lasten ja nuorten käytöshäiriöiden kohtaaminen. [Facing children's and youth's behavioural problems]. Helsinki: Suomen psykologinen instituuttiyhdistys.

Sun, R. C. F. (2015). Teachers' experiences of effective strategies for managing classroom misbehaviour in hong kong. Teaching \& Teacher Education, 46, 94-103. doi:10.1016/j.tate.2014.11.005 
Lanas, Maija, Petersen, Eva Bendix, Brunila, Kristiina (2020) The discursive production of misbehaviour in professional literature. Critical Studies in Education.

DOI:10.1080/17508487.2020.1771604

Sørlie, M. -., \& Ogden, T. (2007). Immediate impacts of PALS: A schoolwide multi-level programme targeting behaviour problems in elementary school. Scandinavian Journal of Educational Research, 51(5), 471-492. doi:10.1080/00313830701576581

Thiem, A. (2014). The Art of Queer Rejections: The Everyday Life of Biblical Discourse. Neotestamentica, 48(1), 33-56.

Toshalis, E. (2010). From disciplined to disciplinarian: The reproduction of symbolic violence in pre-service teacher education. Journal of Curriculum Studies, 42(2), 183-213. doi:10.1080/00220270903267972

Turunen, M. (2008). Helsingin terveyskeskuksen lasten arviointipoliklinikan käytöshäiriöprojekti 2003-2007. [The disturbing behaviour project of the assessment clinic of the health care centre of Helsinki 2003-2007]. Helsinki: Helsingin kaupungin terveyskeskus : jakelu: Sosiaali- ja terveydenhuollon tietopalvelu.

Wadesango, N. (2013). Nature of teacher participation in the formulation and implementation of school-based student discipline policies. Anthropologist, 15(3), 361-367.

Watson, K., Millei, ZS. \& Petersen, E.B (2018) 'The Elephant in the Room': The discursive production of the 'normal' in the early childhood classroom, International Critical Childhood Policy Studies Journal

Wheatley, R. K., West, R. P., Charlton, C. T., Sanders, R. B., Smith, T. G., \& Taylor, M. J. (2009). Improving behaviour through differential reinforcement: A praise note system for elementary school students. Education \& Treatment of Children, 32(4), 551-571.

Vieno, A., Gini, G., Santinello, M., Lenzi, M., \& Nation, M. (2011). Violent behaviour and unfairness in school: Multilevel analysis of italian schools. Journal of Community Psychology, 39(5), 534-550. doi:10.1002/jcop.20450

Youdell, D. (2003). Identity traps or how black students fail: The interactions between biographical, sub-cultural, and learner identities. British Journal of Sociology of Education, 24(1), 3-20. doi:10.1080/0142569032000043579 